\title{
西洋絵画における空間表現の心理的評価と構図特性との関係の研究 STUDY ON RELATIONSHIP BETWEEN PSYCHOLOGICAL EVALUATION AND
COMPOSITIONAL CHARACTERISTICS OF SPATIAL REPRESENTATIONS IN
WESTERN PAINTINGS
}

\author{
松下希 和* \\ Kiwa MATSUSHITA
}

\begin{abstract}
The objective of the research is to analyze the psychological evaluation of the spatial representation in the Western paintings to obtain the insights to the reception of the architectural images. The psychological evaluation experiment based on the SD methods was conducted to quantitatively measure the impression of the spatial representation by the viewers. The factor analysis was conducted in order to capture the psychological evaluation structure, and 7 factors are obtained. The Cluster Analysis was performed to categorize 5 distinctive types of the reception from the psychological evaluations, $<$ Consciousness-Types $>$. The analysis of the $<$ Consciousness-Types $>$ as well as $<$ Element Composition $>$ and $<$ Focus-Zone $>$ types obtained from the Indication Experiments showed the certain relationship between the psychological evaluations and compositional characteristics.
\end{abstract}

Keywords : Western Paintings, Psychological Evaluation, Composition, Elements, Cosciousness-types 西洋絵画, 心理的評価, 構図, 構成要素, 意識型

\section{1. 研究背景・目的}

建築の二次元的な表現のひとつである透視図は、直感的な理解が 容易で、専門的なリテラシーが不要なため、建築がどのように見え るかを、特に建築の専門外の人に伝達するプレゼンテーションの手 段としてきわめて有効なものである。透視図は平面図や断面図のよ うな基本図面と異なり、寸法などの情報を示さない代わりに、その 建物の表情や性質、たたずまいを表現することができる。そのよう な二次元的な空間の性質は建築物単体だけでなく、それが立地する 環境や樹木、人物のような添景との複合的な構成によって表現され る。

筆者は建築、および建築空間が、ドローイングや絵画など二次元 的なメディアに表象化される際の問題を、それを見る者がどのよう に認知し、意識するかを考察や実験を通した検証に付す研究を行っ ている。これまで、建築の二次元的表現は、描く側の視点で、四法 などが論じられることが多く、それがどのように受け止められてい るか、という考察はあまりなされてきていない。本編はそのような 枠組みの中で、筆者らの既往研究（以下前編） ${ }^{1)}$ にき続いて、西洋 絵画に描かれた空間を研究対象としている。

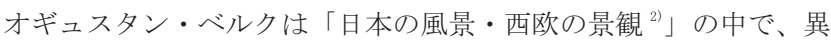
なる歴史的、文化的背景によって差異が生じる風景（画）の知覚の
され方を論じ、それを「知覚の図式」と定義している。ベルクは、 山や森が「長い間、今日われわれが考える意味での自然の風景では なかった。すなわち大きな美的価值を付与された風景ではなかった のである」と書いているが洋1)、風景画といわれているものにしても、 美や道徳、宗教観などの時代の変化とともにその意味は違っており、 現代の我々がそれを正しく理解するためには、その時代時代の主体 の視線に合わすことができる、専門的な美術の造詣が必要となる。

しかし、この「知覚の図式」には文化的・教養的なレベルに何層 ものレイヤーがある。例えば、近代的な主体を確立した透視画法に 則って描かれた絵は、実際の視知覚とは異なる形式化された空間表 現であるにも関わらず、一般的に直感的な理解が容易であるという ことは、それが現代では広く文化に埋め込まれた基底的な「知覚の 図式」基づいているからだと言える。

本研究は、より一般的な人々が空間構成に対してもつ共通のイメー ジがいかに形成されるかを定量的に明らかにすることにより、建築 の二次元的表現の認知や印象に関寸る理解を深め、今後の建築の伝 達力に対する基礎的知見を得ることを目的とする。そのため、調查 対象は西洋絵画であるが、鑑賞されるべき美術作品としてではなく、 我々の現在の文化圈に浸透している透視図をはじめとする、空間の 二次元的表現を発展させたイメージとして扱っており、その中で建

* 東京電機大学未来科学部建築学科 准教授 ·修士(建築学) Assoc. Prof., Dept. of Architecture, School of Science and Technology for Future, TDU, M.Arch. 
築がどのように認知されるかを分析している。

ヴァルター・ベンヤミンは「精神の集中を要求する芸術」と大衆 による「散漫な気晴らし」を対置しているが、我々の関心の中心で ある建築に関しては、「建築は、古来、つねに人間の集団が散漫に接 してきた芸術の典型であった」としている。それは「実際型」であり、 「習慣化」に負う所が大きい芸術であると書いている洋22。二次元的に 表現された空間を特徵づける構成要素や構図の分析を行った前編に 引き続き、本稿はそのように、必ずしも「精神の集中」や画家の意 図や時代背景などの芸術的な知識を伴わない場合でも、人々に共有 されている「知覚の図式」(認知のフォーマット) の一端を、絵画に 対する心理的評価の側面とそれを醸成する空間構成の構図特性の関 係を分析することで、明らかにしようとするものである。

研究の流れを図 1 に示す。

前編では後期ルネッサンスから近代までの代表的な絵画 39 点に対 して、二次元的に表現された空間において印象に残る要素とその構 成を把握するために行った〈指摘法実験〉の結果について報告した。 そこでは、まず(1)絵画を特徵づける要素の構成を指摘率の低減傾向 によって 5 タイプに類型化し、絵画に描かれた空間の奥行きや広が りとの関係を分析した。(2)指摘されやすい要素の特徴と構成を捉え るため、指摘要素を「建築」「人物」「樹木」「空」「その他」の 5 つ のカテゴリーに分類し、その傾向を表わす 4 つの〈要素構成型〉に 類型化した。その結果、「人物」要素がもっとも指摘を受けやすいこ とが明らかになった。(3)画面の中で指摘を受けた要素の位置（注目 域）の特徵を明らかにするため、指摘要素の画面上の配置をグリッ ド解析し、6つの〈注目域分布型〉に類型化して示した。(4)指摘率は 高いが印象の強弱を示寸指摘度は低い要素を「仮面の主題」と定義し、 その要素の特性と注目域分布型のタイプとの関係性を論じた。

続く本編では代表的な西洋絵画に描かれた建築要素を含む空間の 雰囲気を捉えるために (1)〈心理的評価分析〉を行う。具体的には SD 法による心理的評価実験で得た心理量から心理的評価構造を分析す る。(2)心理特性を表す〈意識型〉を抽出し、それぞれの絵画の特徴 との関係を分析する。また、(3)〈指摘法実験〉により得られた指摘 要素の構成や構図の特徴と心理的評価の傾向との相互関係を総合的 に明らかにする。

都市・建築空間分野から西洋絵画の空間について探った既往諸研 究については前編で報告している。日本絵画の空間を対象とした研 究では絵巻物などの空間表現を分析した植田宏らの一連の研究 ${ }^{4)} や 、$ 浮世絵の遠近法とその心理的効果について心理学の分野から論じた 仲谷兼人 ${ }^{5)}$ の研究等がある。いずれも主として作画する側の視点で 表現技法を扱っており、絵画を見る者がそれをどのように受け止め ているかを数量的に扱う本研究の目的とは異なっている。

空間の雾囲気とその意識の構成を明らかにする既往研究としては、 積田洋、濱本紳平の代表的な街路や都市空間の雾囲気の構造とそれ を構成する印象に残るエレメントの関係を分析した研究 6,7 がある。 本研究は、これらの研究手法を用いて西洋絵画に描かれた建築やそ の他の構成要素によって表現される空間を対象に、人々が絵画に描 かれた空間に対して感じる共通の心理的評価と構図の関係を明らか にし、建築の二次元的表現の意識に関寸る理解を深めて、建築や空 間表現の伝達力を高めるための基礎的資料を得ることを目的とする。

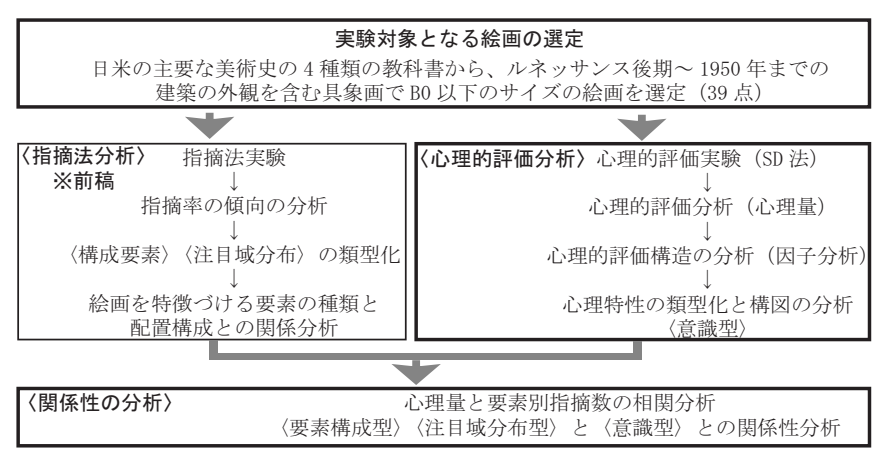

\section{図 1 研究フロー}

\section{表 1 分析対象絵画リスト}

\begin{tabular}{|c|c|c|c|}
\hline タイトル & 略名 & 画家名 & 年 \\
\hline The Tempest & TEM & Giorgione & 1510 \\
\hline The Judgment of Paris & JOP & L. Cranach the Elder & 1528 \\
\hline The Blind Leading the Blind & BLB & P. Bruegel the Elder & 1568 \\
\hline Allegory of Sight & $\mathrm{AOS}$ & J.Brueghel, P.Rubens & 1617 \\
\hline Pelkus Gate near Utrecht & UTR & Jan van Goyen & 1646 \\
\hline A Pastoral Landscape & PAS & Claude Lorrain & 1648 \\
\hline View of Delft & VDE & Johannes Vermeer & 1661 \\
\hline Bleaching grounds near Haarlen & HAA & Jacob van Ruisdael & 1670 \\
\hline Avenue at Middelharnis & AMH & Meindert Hobbema & 1689 \\
\hline Mezzetin & MEZ & J.-A. Watteau & 1718 \\
\hline The Bucintoro at the Molo & BMO & Canaletto & 1732 \\
\hline Soap Bubbles & SBB & Jean Chardin & 1733 \\
\hline The Swing & TSW & J.-H. Fragonard & 1767 \\
\hline Old Man and Death & OMD & Joseph Wright & 1773 \\
\hline Cornelia Presenting Her Children & $\mathrm{CPC}$ & Angelica Kauffmann & 1785 \\
\hline View of Rome & VOR & Camille Corot & 1827 \\
\hline The Gleaners & GLE & Jean Francois Millet & 1857 \\
\hline On the Bank of the Seine & SEI & Claude Monet & 1868 \\
\hline Beata Beatrix & BEB & D. G. Rossetti & 1870 \\
\hline Max Schmitt in a Single Scull & MAX & Thomas Eakins & 1871 \\
\hline Snap the Whip & STW & Winslow Homer & 1872 \\
\hline Villa at the Seaside & VSE & Berthe Morisot & 1874 \\
\hline The House at Rueil & HRU & Edouard Manet & 1882 \\
\hline The Sacred Grove & GRO & Puvis de Chavannes & 1884 \\
\hline Mont Sainte Victoire & MSV & Paul Cezanne & 1887 \\
\hline The Harvest & THA & Vincent van Gogh & 1888 \\
\hline Gray Weather, Grande Jatte & GWG & Georges Seurat & 1888 \\
\hline The Scream & SCR & Edvard Munch & 1893 \\
\hline La Place du Thetre Francais & PTF & Camille Pisarro & 1898 \\
\hline Landscape with Red Trees & LRE & Maurice de Vlaminck & 1907 \\
\hline Sixth Avenue and $30^{\text {th }}$ Street & SAS & John Sloan & 1909 \\
\hline Mystery and Melancholy of a Street & MMS & Giorgio de Chirico & 1914 \\
\hline Villa R & VIR & Paul Klee & 1919 \\
\hline Kizette in Pink & KIP & Tamara de Lempicka & 1926 \\
\hline My Egypt & MEG & Charles Demuth & 1927 \\
\hline New York, Night & NYN & Geogia O'Keeffe & 1929 \\
\hline American Gothic & AGO & Grant Wood & 1930 \\
\hline Early Sunday Morning & ESM & Edward Hopper & 1930 \\
\hline Christina's World & CHW & Andrew Wyeth & 1948 \\
\hline
\end{tabular}

\section{2. 分析対象絵画の選定と実験概要}

分析対象の選定にあたっては、米国と日本の大学・高校教育の 西洋美術史の代表的な教科書である、『Janson's History of Art: Western Tradition』の 8 版 ${ }^{8}$ 、『Gardner's Art Through Ages』の 12 版 ${ }^{9)}$ 、『カラー版 西洋美術史』 ${ }^{10)}$ 、そして『高校美術 $1 ・ 2 』{ }^{11)}$ に 掲載されている絵画のうち、幾何学的遠近法が確立し、また画家と 建築家の境界が曖昧であったルネッサンスから近代までの間で建築 物注3) が描かれた全ての具象画を無作為に抽出した。建築には外観と 内部空間の空間表現があるが、同一の実験では評価が困難と判断し、 本編では外観が描かれている絵画のみを扱った。建築の外観には、 一部分がクローズアップされているものや、遠景に群として描かれ ているものなど、さまざまなケースが含まれる。宗教画は特有の象 徵体系があるため対象から外し、本研究が最終的に目指寸設計図面 の表現との関連を考慮して、絵画のサイズはB0（1030X1456 mm）以 内とした。また、個別の画家に偏らないように、一画家あたり一作 


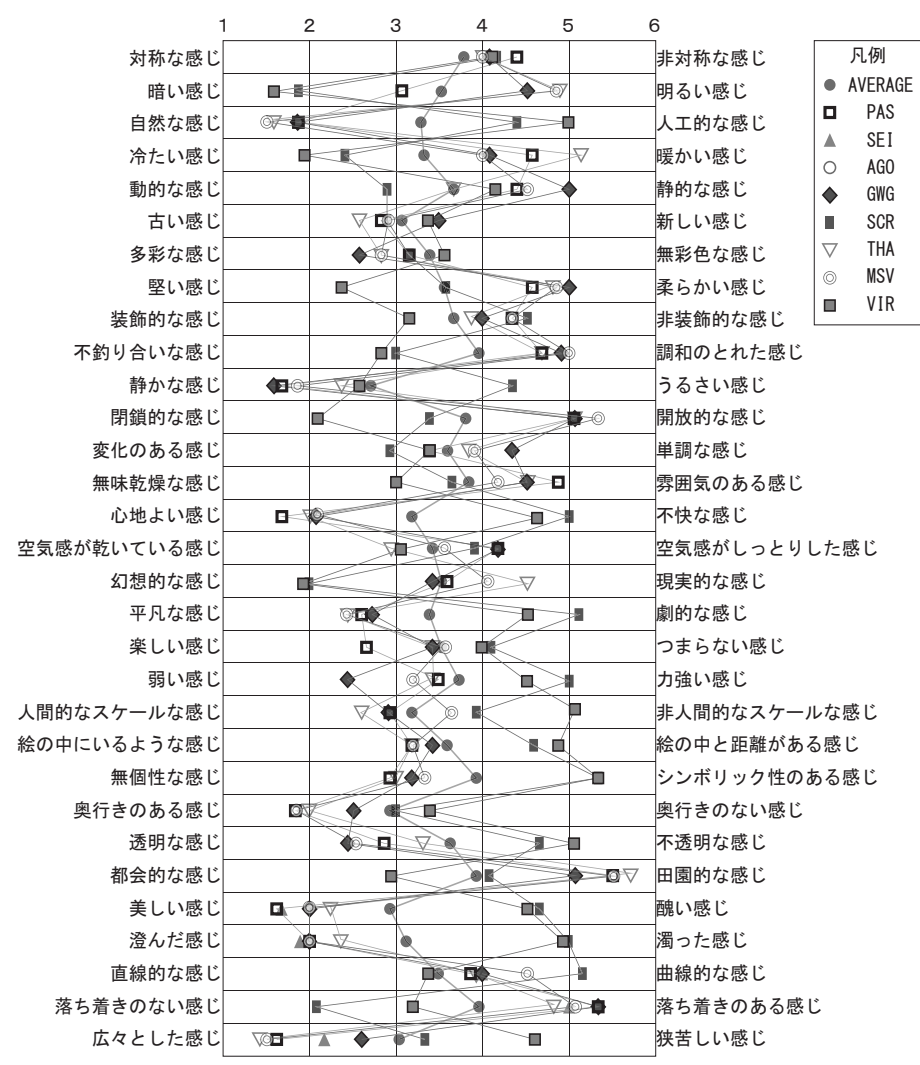

図 2 心理量図と主な分析対象絵画

品としたところ、分析の対象絵画数は 39 点となった（表 1）。

人々が西洋絵画における二次元的空間をどのように感じているか を定量的に測るため、SD 法実験による〈心理的評価実験〉洋) を行った。 $\mathrm{SD}$ 法の評価尺度は、一部を既往研究注5) 参考に選定し、さらに絵 画における空間を評価するために必要と思われる評価尺度を加えて、 予備実験を行った上、6 段階評価注 6 によよる 31 心理評価尺度を用いた (図 3)。実験の方法としては、対象絵画の画像を高解像度注》) で原寸 大に出力し、絵の中央が床から $1.5 \mathrm{~m}$ の高さになるよう壁に掲示して、 建築学科と建築・デザイン学科の学生 50 名 (男性 22 名、女性 28 名) ${ }^{\text {i土8) }}$ に、絵画のタイトルや画家の名前などを伝えずに注9)、それぞれの 絵画の対角線の 2 倍の距離から観覧し、評価してもらった。

\section{3. 心理的評価分析}

$\mathrm{SD}$ 法実験の結果を各絵画ごとに集計し、心理的評価の平均值（心 理量）と標準偏差を求めた。39 点の絵画の中で 7 個以上の評価尺度 で心理量が 5 以上または 2 以下であった 6 点を特徽的な心理的評価 を持つ絵画として全体の平均と共に図 2 に示す。その中で最も特徵 的な絵画は【PAS】と【MSV】であった。両方とも主に自然の情景を 描いた風景画で、<自然的な感じ $><$ 静かな感じ $><$ 開放的な感じ $><$ 奥行きのある感じ $><$ 田園的な感じ $><$ 美しい感じ $><$ 落ち着 きのある感じ>などで共通して評価が高かった。【SEI】【THA】な゙ の他の風景画にも同様の評価傾向が見られた。これらは標準偏差も 小さかったことから、風景画に対して見る者が比較的共通した印象 をもつことが推測できる。他方、背景が自然風景であっても、前景 で耳を塞ぐ人物が主題である【SCR】や、抽象的で幻想的な背景に建 物や月が描かれている【VIR】は＜暗い感じ $><$ 幻想的な感じ $><$ 劇

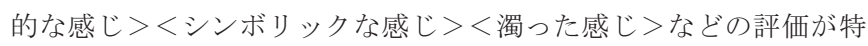
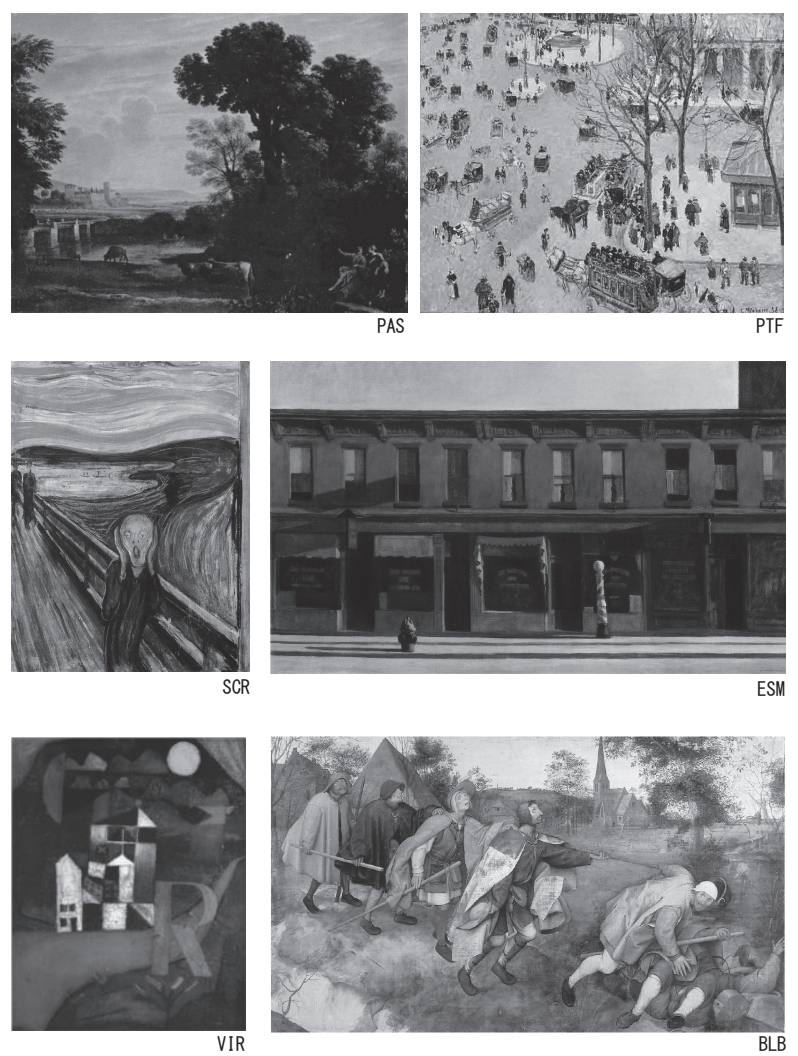

表 2 心理因子負荷量表

\begin{tabular}{|c|c|c|c|c|c|c|c|}
\hline 変数名 & 1 & II & III & IV & $\mathrm{V}$ & $\mathrm{VI}$ & VII \\
\hline 暗い感じ－明るい感じ & (2) & & & & & & \\
\hline 冷たい感じー暖かい感じ & (2) & & & & & & \\
\hline 多彩な感じー無彩色な感じ & $\mathbf{A}$ & & & & & & \\
\hline 心地よい感じー不快な感じ & $\mathbf{\Delta}$ & & & & & & \\
\hline 堅い感じー柔らかい感じ & $\triangle$ & & & & & & \\
\hline 楽しい感じーつまらない感じ & $\mathbf{A}$ & & & & & & \\
\hline 不釣り合いな感じー調和のとれた感じ & $\square$ & & & & & & \\
\hline 静かな感じーうるさい感じ & & $\mathbf{0}$ & & & & & \\
\hline 動的な感じー静的な感じ & & (2) & & & & & \\
\hline 落ち着きのない感じー落ち着きのある感じ & & 0 & & & & & \\
\hline 変化のある感じー単調な感じ & & 0 & & & & & \\
\hline 装飾的な感じー非装飾的な感じ & & $\square$ & & & & & \\
\hline 広々とした感じー狭苦しい感じ & & & (a) & & & & \\
\hline 閉鎖的な感じー開放的な感じ & & & - & & & & \\
\hline 奥行きのある感じ一奥行きのない感じ & & & $\triangle$ & & & & \\
\hline 幻想的な感じー現実的な感じ & & & & $\mathbf{0}$ & & & \\
\hline 平凡な感じー劇的な感じ & & & & 0 & & & \\
\hline 無個性な感じーシンボリック性のある感じ & & & & $\triangle$ & & & \\
\hline 人間的なスケールな感じー非人間的なスケールな感じ & & & & $\square$ & & & \\
\hline 澄んだ感じー濁った感じ & & & & & 0 & & \\
\hline 美しい感じ－醜い感じ & & & & & $\triangle$ & & \\
\hline 透明な感じー不透明な感じ & & & & & $\square$ & & \\
\hline 都会的な感じー田園的な感じ & & & & & & $\triangle$ & \\
\hline 直線的な感じ一曲線的な感じ & & & & & & $\triangle$ & \\
\hline 自然的な感じー人工的な感じ & & & & & & $\Delta$ & \\
\hline 古い感じ－新しい感じ & & & & & & $\mathbf{\square}$ & \\
\hline 弱い感じーカ強い感じ & & & & & & $\mathbf{\square}$ & \\
\hline 対称な感じ－非対称な感じ & & & & & & $\square$ & \\
\hline 無味乾燥な感じ一雰囲気のある感じ & & & & & & & $\square$ \\
\hline 空気感が乾いている感じー空気感がしっとりした感じ & & & & & & & $\square$ \\
\hline 固有値 & 6.8 & 4.1 & 2.1 & 1.7 & 1.3 & 1.1 & 1.1 \\
\hline 寄与率 & 12.1 & 8.8 & 7.7 & 6.0 & 5.6 & 5.5 & 2.8 \\
\hline 累積寄与率 & 12.1 & & & 34.5 & & & 48.4 \\
\hline
\end{tabular}

\section{表 3 代表心理因子軸}

\begin{tabular}{|c|c|c|}
\hline No. & 因子名 & 代表的心理尺度 \\
\hline 1 & 快適性因子 & 暗い感じー明るい感じ \\
\hline II & 多イナミック因子 & 動的な感じー静的な感じ \\
\hline III & 開放性因子 & 広々とした感じー狭苦しい感じ \\
\hline IV & ドラマティック因子 & 平凡な感じー劇的な感じ \\
\hline $\mathrm{V}$ & 澄清的因子 & 澄んだ感じー濁った感じ \\
\hline $\mathrm{VI}$ & アーバニティ因子 & 都会的な感じー田園的な感じ \\
\hline VII & アンビエンス因子 & 無味乾燥な感じ－雾囲気のある感じ \\
\hline
\end{tabular}


徵的であった。必ずしも暗い色調の絵でないにも関わらず、このよ うな評価を受ける一因として、空間が透視図法に則って作図されて いない点が挙げられる ${ }^{\text {住10 }}$

\section{4. 心理的評価構造の分析}

二次元的に表現された空間の心理的評価構造を明らかにするため、 39 点の絵画について得られた心理評価尺度に対する心理量を変量と して因子分析 (バリマックス回転) 注11) を行い、因子負荷量を算出し た（表 2)。実験では 31 の形容詞対句を使用したが、心理量の標準 偏差を確認したところ、多くの絵画でく絵の中にいるような感じー 絵の中と距離がある感じ>の標準偏差が 1.5 以上あり、評価が分散 しているため、見る者に理解されにくい尺度であったと判断し、除 外した。よって、因子分析は 30 評価尺度で行い、結果として固有值

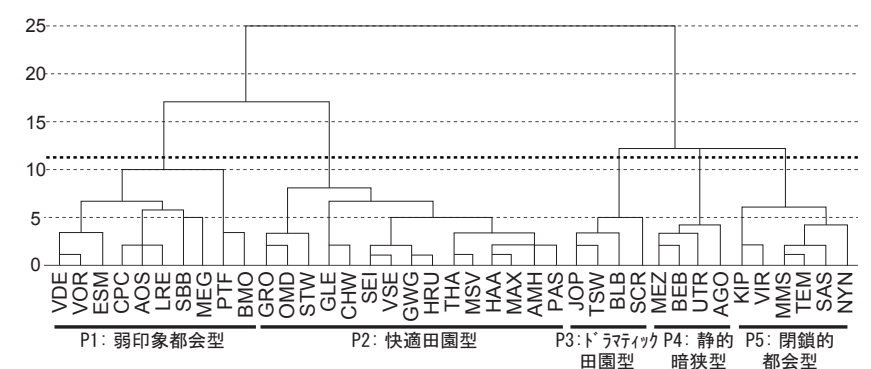

図 3 代表心理因子によるクラスター図
1 以上の心理因子軸が評価軸として第VII軸得られた。第 I 心理因子 軸は＜暗い感じ一明るい感じ>、〈冷たい感じ一暖かい感じ＞など の評価尺度で構成され、絵画空間の明るさや心地よさを表す軸と言 えることから、〈快適性因子〉と寸る。第 II 心理因子軸は＜静かな 感じ一うるさい感じ $>$ 、 <動的な感じ一静的な感じ $>$ 、 <落ち着き のない感じ一落ち着きのある感じ>などで構成され、動きを表現す る軸と言えるので、〈ダイナミック因子〉と呼ぶ。第III 心理因子軸 は<広々とした感じ一狭苦しい感じ $><$ 閉鎖的な感じ一開放的な感 じ>などで構成されることから、絵画空間の広がりの度合いを表し ている軸と言えるので〈開放性因子〉とする。第 $\mathrm{IV}$ 軸は＜幻想的な 感じ一現実的な感じ ><平凡な感じ一劇的な感じ>などで構成され、 絵画空間のドラマ性を表す軸と言えるので〈ドラマティック因子〉 とする。第 $\mathrm{V}$ 軸は＜澄んだ感じ一濁った感じ ><美しい感じ一醜い 感じ>の評価尺度で構成され、清濁の度合いを軸と言え、〈澄清的因 子〉とする。第VI軸は＜都会的な感じ一田園的な感じ $><$ 直線的な 感じ一曲線的な感じ $><$ 自然的な感じ一人工的な感じ $>$ な゙゙の評価 尺度で構成され、絵画空間が表現する都会・田園の度合いを表現し ている軸と言えることから、〈アーバニティ因子〉とし、第VII軸は $<$ 無味乾燥な感じ一雰囲気のある感じ>の評価尺度で構成され、空間 の䨌囲気を表す軸と言えることから〈アンビエンス因子〉とする。 以上の第 $\mathrm{I} \sim \mathrm{VII}$ 心理的評価軸までで、 $48.4 \%$ の累計寄与率を示して

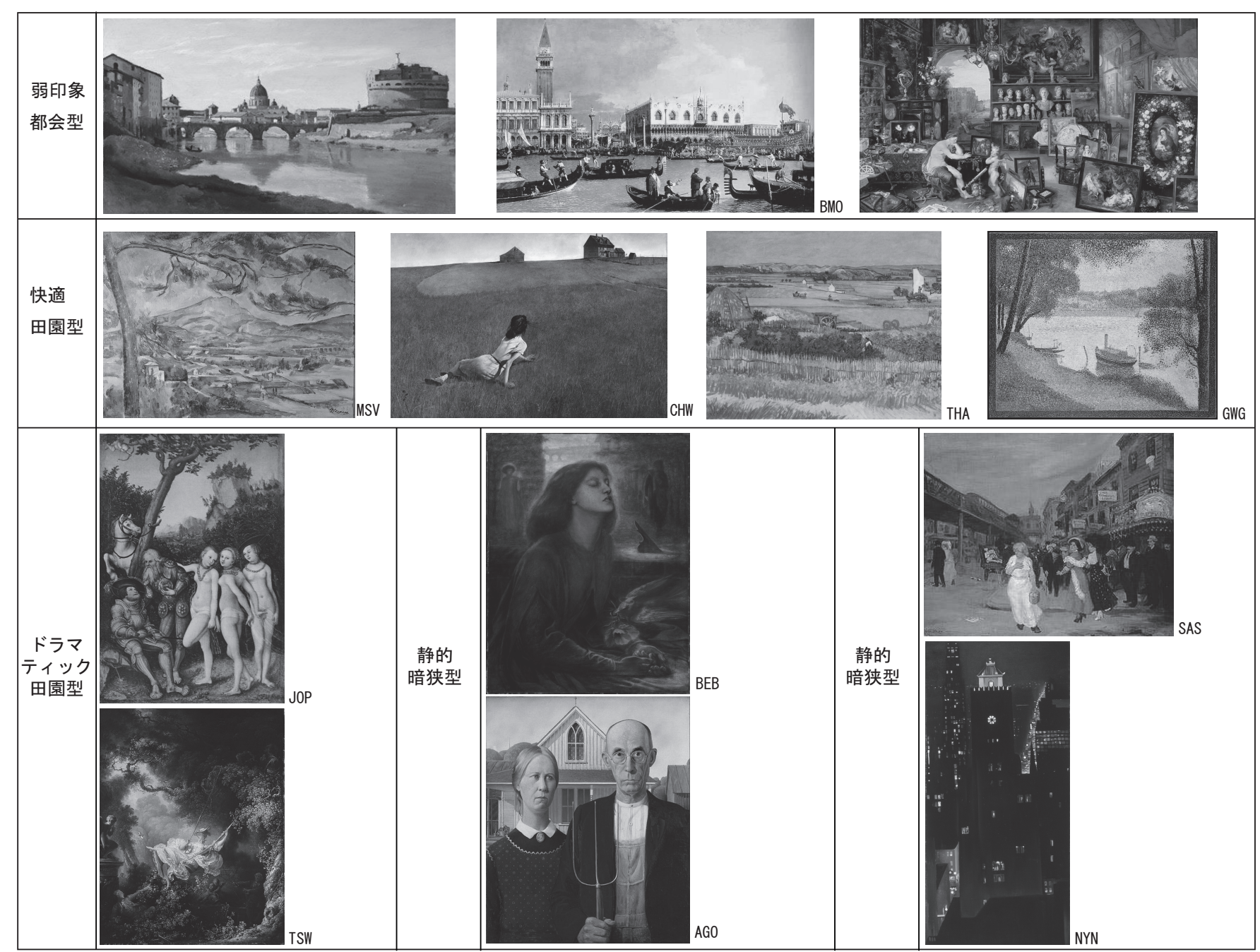

図 4〈意識型〉別絵画の分類 
いる。本編ではこれら 7 つ因子から代表心理的評価尺度を選出し、 後述の分析に用いる (表 3)。

\section{5. 心理特性の類型化と構図の分析}

二次元的に表現された空間に対しての心理的評価の傾向から、い 〈つかの特性的な心理的評価の型〈意識型〉を抽出するため、各絵 画についての 7 つ代表心理的評価尺度の心理量を類似度とし、ク ラスター分析（最遠隣法） 注12) を行った。その結果、5つのタイプに 分類された（図 3,4$)$ 。

分類した絵画の 7 つ代表心理尺度の平均值をレーダーチャート にプロットし、それらの構図的特性を分析した（図 5)。ひとつめの タイプは＜都会的な感じ $>$ と $<$ 明るい感じ $>$ 以外は評価が全体の平 均值に近く中庸で、目立った特性のないタイプで「弱印象都会型」 と呼ぶ。【VDE】【ESM】【SBB】【PTF】がこれに分類された。このタイ プの特徵は横型の構図に正対した建物が描かれている安定した構図 が多いことである。必ずしも都市を描いた絵ばかりではないにもか かわらず＼cjkstart都会的な感じ>と評価されているのは、建物が多く描か れ、樹木の存在感が薄いためと考えられる。また、画面の下辺に平 行に道や川が配置されており、水平ラインが強調されていること、 そして人物の存在感が比較的薄かったり、皆無であったりする絵が 多いことも共通した特徴である。

\section{横型構図}

P1：弱印象都会型 VDE, VOR, ESM, CPC, AOS, LRE, SBB, MEG, PTF, BMO
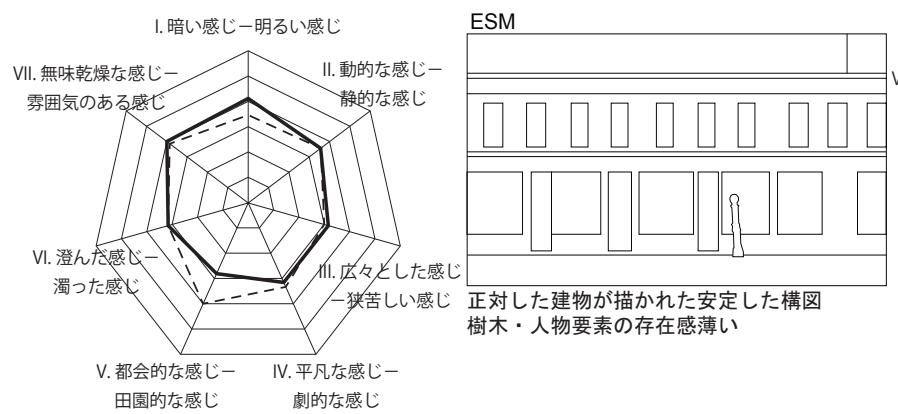

ふたつめは＜暗い感じ一明るい感じ $><$ 動的な感じ一静的な感じ $><$ 無味乾燥な感じ一雰囲気のある感じ $>$ の評価は「弱印象都会型」 に類似しているものの、<田園的な感じ $><$ 広々とした感じ $><$ 澄 んだ感じ >の評価が高いことが特徵的な「快適田園型」で、【PAS】SEI】 【HAA】【MAX】【GLE】がこれに分類された。「弱印象都会型」と同様に 横型で水平に水の要素が配されている安定した構図が多い。「弱印象 都会型」よりは人物の存在感があるが、小さいか顔を背けている場 合が多く、表情が見えないので見る人が感情移入しにくく<劇的な 感じ>に繋がらないと推測される。一方、樹木の要素が多いことに 加えて、建物の要素が「弱印象都会型」のように群としてではなく、 個体として描かれている場合が多いことで＜田園的な感じ $><$ 澄ん だ感じ>に影響していると考えられる。

3つ目のタイプは「田園的な感じ」の評価が高い点は「快適田園型」 と同様だが、<劇的な感じ $><$ 動的な感じ $><$ 狭苦しい感じ $>$ が特 徵的なことから「ドラマティック田園型」とする。【JOP】【TSW】な どが分類された。このタイプは 4 点中 3 点が縦型の構図で、主に自 然環境の中に複数の人物が描かれている。共通して人物の表情が豊 かで動きがあり、全身が描かれていることが、劇的で動的な雾囲気 を作り出していると考えられる。

4 つ目は＜静的な感じ $><$ 暗い感じ $><$ 狭苦しい感じ $><$ 濁った感 じ>などのネガティブな評価が特徵的なタイプで「静的暗狭型」と
縦型構図

P3：ドラマティック田園型 JOP, TSW, BLB, SCR
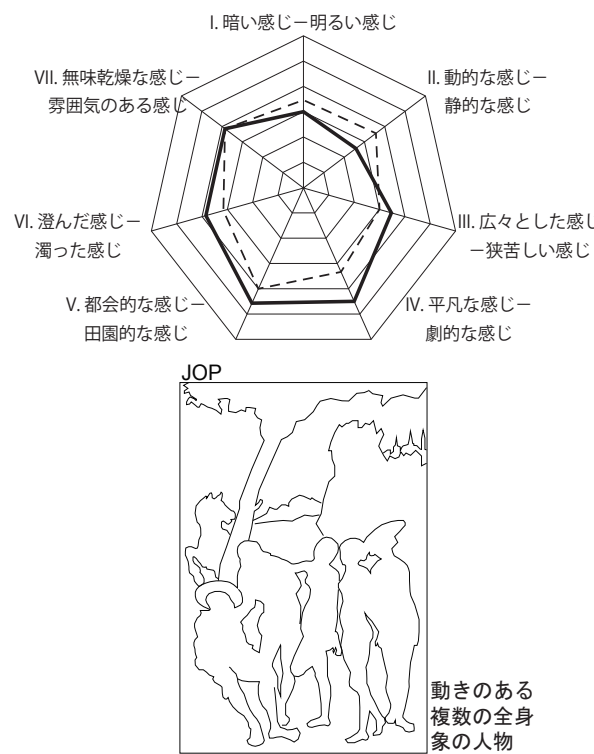

P4: 静的暗狭型 MEZ, BEB, UTR, AGO

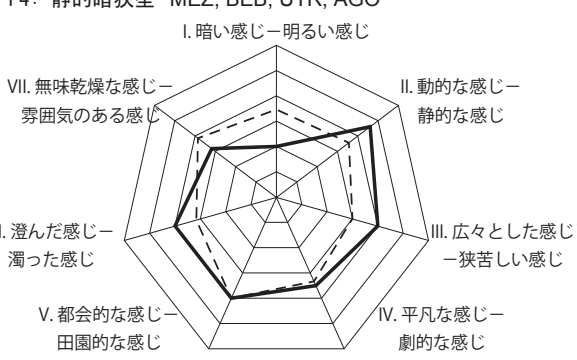

AGO

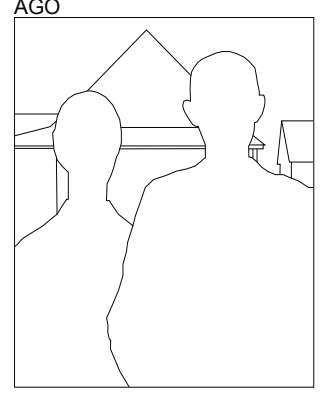

前景と背景の 奇妙な距離感
P2：快適田園型 GRO, OMD, STW, GLE, CHW, SEI, VSE, GWG, HRU, THA, MSV, HAA, MAX, AMH, PAS

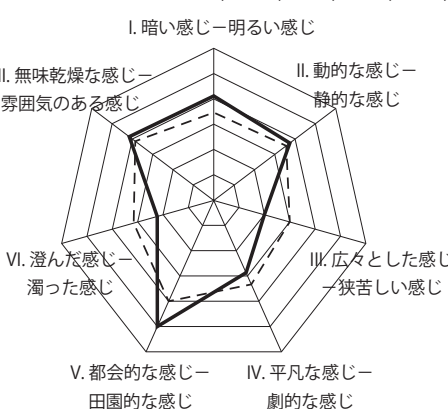

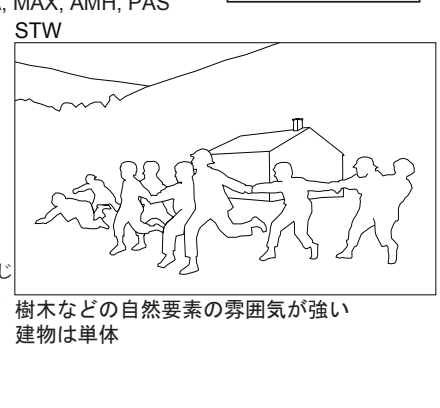

P5：閉鎖的都会型 KIP, VIR, MMS, TEM, SAS, NYN

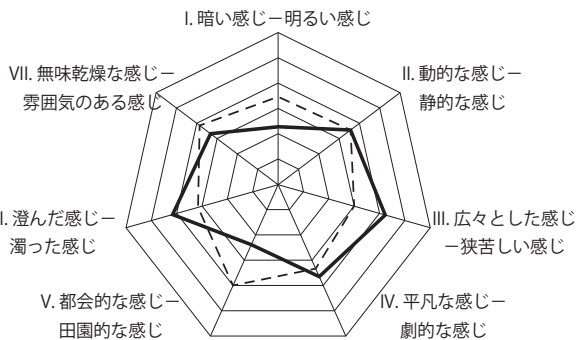

MMS

図法に則って作図 されていない透視 図から生み出さ れる歪んだ空間

図 5 〈意識型〉とその構図的特性 
寸る。【BEB】や【AGO】がこのタイプである。これも 4 点中 3 点が縦 型の構図であり、【UTR】以外は前景に動きの少ない 1,2 人の人物が 描かれている特徴がある。

最後のタイプは「静的暗狭型」と<暗い感じ $><$ 狭苦しい感じ $>$ ＜濁った感じ＞などで類似した評価を受けたもので、＜静的な感じ >はそれほど強くない代わりに<都会的な感じ>が強い「閉鎖的都 会型」である。【MMS】SAS】などがこれに分類された。このタイプ も 6 点中 5 点が縦型の構図である。樹木の要素が少なく、建物の存 在感が大きい絵が多いことが＜都会的な感じ＞に影響していると考 えられる。一点透視図的な奥行きのある風景が描かれているにも関 わらず、狭苦しく濁った雾囲気を醸し出しているのは、透視図が透 視図法に則って描かれていないことから、見る人の立ち位置や絵の 中の要素との距離が不明瞭で不安定に感じさせるためと推測できる。

〈意識型〉の構図の向きの傾向を見ると、「弱印象都会型」と「快 適田園型」は主に横型、「ドラマティック田園型」「静的暗狭型」「閉 鎖的都会型」は主に縦型の構図に分けられた。横型、縦型別に主要 因子の心理量を比較すると、横型の方が広々として明るいといった 空間の質や広がりに関する評価を受ける傾向が見られた。一方、縦 型は比較的＜劇的な感じ>の評価が高く、また「ドラマティック田 園型」では＜動的な感じ>、「静的暗狭型」では＜静的な感じ>のよ うに〈ダイナミック因子〉の評価尺度においては正反対の評価が見 られた。横の視野が狭い分、より空間で起きている事柄や動作に関 することが注目を集めていると推測できる。

\section{6. 心理量と要素別指摘数の単相関分析}

印象に残る構成要素と絵画から受ける心理的評価との相関関係を その強弱も含めて定量的に把握し、両者の関係を明らかにするため、 前編で「人物」「建築」「樹木」「空」「その他」のカテゴリー別に分 類した指摘数と代表心理因子軸の心理量の相関分析を行った。 $\mathrm{t}$ 検定 を行った結果、 $\mathrm{r}=0.32$ 以上が有意水準 $5 \%$ 有意であることがわかった。 その関係を明らかにするため、回帰直線を示した単相関図を作成し た（図 6-1, 2,3,4）。

要素別に見ると「樹木」が＜明るい感じ $>$ 、《広々とした感じ $>$ 、 ＜澄んだ感じ＞、＜田園的な感じ＞など、もっとも多くの心理因子 軸との相関性を示した。「樹木」の要素が印象的であればあるほど、 全般にポジティブな䨌囲気が感じられることがわかる(図 6-1,2)。〈意 識型〉別にははっきりとした相関は見られないが、「弱印象都会型」 と「快適田園型」では樹木の要素の印象が強く「明るく」「田園的」 な評価だが、閉鎖的都会型」では樹木の印象は弱く「暗く」「都会的」 と感じられていることがわかる。

一方、もっとも指摘を受けやすい要素である「人物」は<動的な 感じ>やく劇的な感じ>と相関を示した。これは人物が動きや表情 を伴いうる要素であると共に、見る人が感情移入しやすい要素であ るため、動的や劇的な感じが得られると推測できる。また、人物は 樹木と正反対に、開放性因子の<狭苦しい感じ>とも相関を示した (図 6-3)。絵画の中に人物が多数描かれていたり、至近距離にいると 空間の広がりが狭くなるイメージが生じることがわかる。「快適田園 型」においては、人物の印象が強まるにつれ、「広々とした感じ」が 弱まる相関が見られた。

「建築」は〈アーバニティ因子〉のく都会的な感じ $>$ と相関を示し

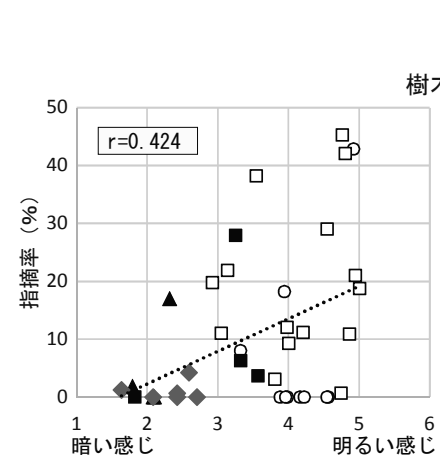

図 6-1「樹木」暗いー明るい

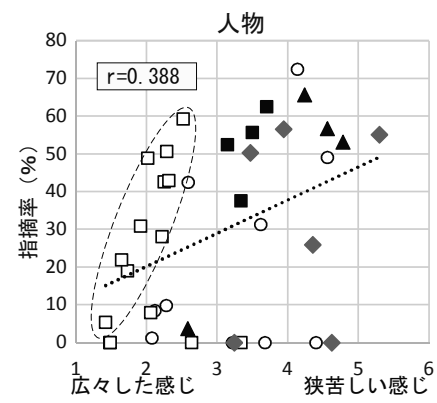

図 6-3「人物」広々-狭苦しい

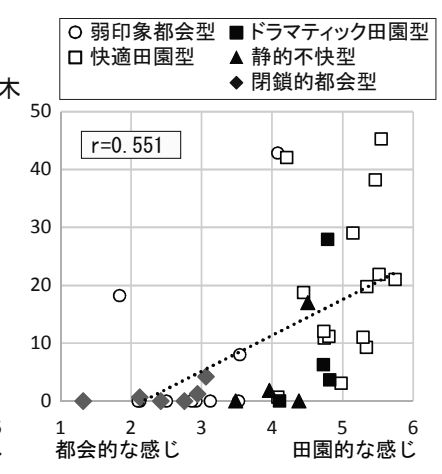

図 6-2「樹木」都会的 - 田園的

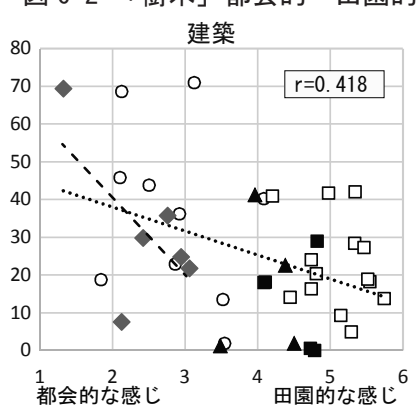

図 6-4 「建築」都会的 - 田園的

た（図 6-4）。樹木とは反対の相関関係だが、樹木よりは相関が強く 見られなかった。〈意識型〉別では、「閉鎖的都会型」が全体よりも 明確に建築の要素の印象が強まると、<都会的な感じ>が強まる傾 向が見られた。空間の広がりに関連する開放性因子と建築要素とは 相関が見られなかった。「その他」の要素はく静的な感じ〉と相関を 示した。「その他」は絵画によって様々な要素が含まれるが、要素を 個別に見ると「山」「湖」「道」など周辺環境に関する指摘が多かっ たためと考えられる。

\section{7.〈指摘法実験〉による類型と〈意識型〉の対応関係の分析}

絵画の印象に残る要素の構成の特徵と意識型の形成との関係を考 察するため、本編の〈意識型〉を用いて、前編の〈指摘法実験〉によっ て類型化した印象の強い要素の構成〈要素構成型〉と画面の中で指 摘を受けた要素の位置である注目域の分布の特徵の類型化〈注目域 分布型〉との対応関係を考察した（図 7,10）。最も目を惹く要素を明 らかにするため、〈要素構成型〉には最も指摘を受けた要素をカテゴ リー別に示した。また、〈意識型〉と絵画の二次元空間の奥行きの広 がりとの関係を分析するため、絵画のタイトルなどから推測される 画家が意図した主題や背景と見る者との距離を、描かれている要素 の大きさや細かさから 6 段階に推定し ${ }^{i * 13}$ 、タイプごとに分類して（図 8）構成との関係を見た。

\section{1 ) 〈要素構成型〉と〈意識型〉}

〈要素構成型〉と〈意識型〉の関係では、まず〈樹木・建築要素 構成型〉が【LRE】以外はすべて「快適田園型」であったが、〈建築 要素構成型〉の絵画は主に「弱印象都会型」が多く、次に「閉鎖的 都会型」であった。建築の印象が強まり、樹木の印象が弱まると〈都 会的な感じ〉になるが〈広々とした感じ〉〈澄んだ感じ〉が減少する 傾向が明らかになった。「樹木・建築要素構成型」の絵画でも、最も 指摘を受けた要素が「樹木」というケースは少ないことからも、前 編で論じたように「樹木」は背景的な要素であるが、その存在は心 
理的評価に大きく影響することがわかる。また、〈その他要素構成型〉 も主に「快適田園型」であったが、このタイプの絵画で指摘された「そ の他」の要素は「山」や「水」などの自然物が多く、「弱印象都会型」 と「閉鎖的都会型」の【AOS】と【MMS】の「その他」の要素は「絵画」 や「荷車」などの人工物であったので、自然物の要素が印象的な絵 は快適な評価になる傾向が明らかになった。

横型の「弱印象都会型」と「快適田園型」には、描かれた年代や 様式に関わらず、画面下部に水平に水の要素（川・海）の要素が配 されている構図を持つ絵が多く見られた(図 8)。横型の構図に加えて、 水平の水の要素があることで比較的＜澄んだ感じ $><$ 明るい感じ $>$ などの評価を受けやすくなる傾向があった。例えば、「弱印象都会型」 の【VDE】と【VOR】は画面上半分を占める空の下に、川と対岸の街 の風景が広がっている非常に似通った構図を取っており（図 8)、両 方とも＜広々とした感じ $><$ 平凡な感じ $><$ 澄んだ感じ $>$ におて 比較的評価が高かった。一方、「快適田園型」の【PAS】と【SEI】も 前景の川岸から水平に流れる川と対岸の風景を描いた構図が「弱印 象都会型」の 2 点と似ているが、<澄んだ感じ $>$ や雾囲気のある 感じ>でより高い評価を受けた。開放性因子軸の<広々とした感じ 一狭苦しい感じ $>$ や閉鎖的な感じ一開放的な感じ $>$ でも「快適田 園型」の 2 点の方が＜広々とした感じ $><$ 開放的な感じ $>$ と評価さ れる傾向が見られた。2 タイプの絵の印象の違いに着目すると、「弱 印象都会型」【VDE】と【VOR】ではもっとも指摘を受けた要素が水要 素の向こう側の「建築」である一方、快適田園型」の【PAS】と【SEI】 は水要素より手前の「樹木」や「人」であった。後者の構成の特徴は、 前景の左または右に大きな樹が描かれ、その足元に人が描かれてい ることである。その人物を起点として見る人の視線を、樹木が縦方向、 中景に描かれた川が水平方向、そして人物の対角線上の遠景に描か れた建物が画面の奥へと導いていると推測できる。「弱印象都会型」 の 2 点にはない、積極的に視線を導くこれらの構図がく開放的な感 じ>に影響していると考えられる。

\section{2 )〈意識型〉と構図特性}

〈人物要素構成型〉は寸べての〈意識型〉に分布しているが、描か れ方や背景との関係などの構図によって心理的評価に対応関係が見 られた。<田園的な感じ＞が強い「快適田園型」と「ドラマティッ ク田園型」は主題は〔近空間 I〕に、主に大自然が描かれた背景は〔遠 空間】にあるものが多い傾向が見られた。主題と背景の間の距離が 長いため、奥行きを感じさせると考えられるが、「快適田園型」のみ ＜広々とした感じ＞の評価が高く、「ドラマティック田園型」はむし ろく狭苦しい感じ>と評価された。ふたつの〈意識型〉において〔近 空間〕にある主題の多くは全身像で描かれた人物であるが「快適田 園型」の人物は $1 、 2$ 人が多い（図 8）一方「ドラマティック田園型」 は 3 人以上がほとんどで、より見る者に近い〔近空間 I〕に立ちはだ かっているため（図 4,5【JOP】）、背景が〔遠空間〕にあるにも関わ らず広がりが感じられないためと考えられる。注目域の分布を見て も「快適田園型」が多い〈十字形型〉〈左下分布型〉には「ドラマティッ ク田園型」の絵画は分類されていない。〈十字形型〉や〈左下分布型〉 のように横向きの構図に、印象に残る要素が縦にコンパクトにまと まり、指摘を受けない余白に背景の広がりが感じられる構図が広々 と開放的な心理的評価を得る傾向が見られた。

一方、「静的暗狭型」は主題と背景の間の距離が短い傾向があった。
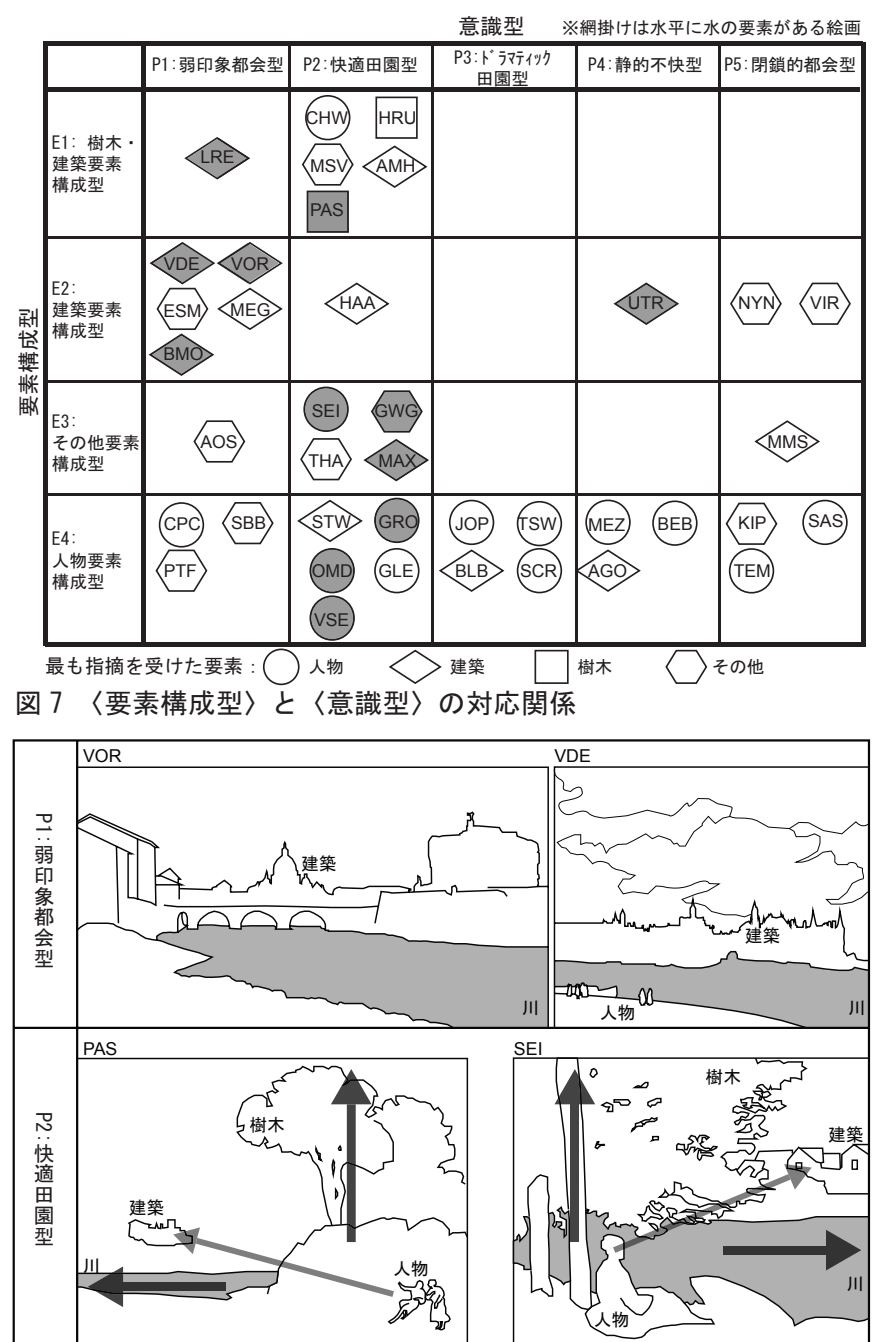

図 8 水平の水要素のある構図の特徵と〈意識型〉

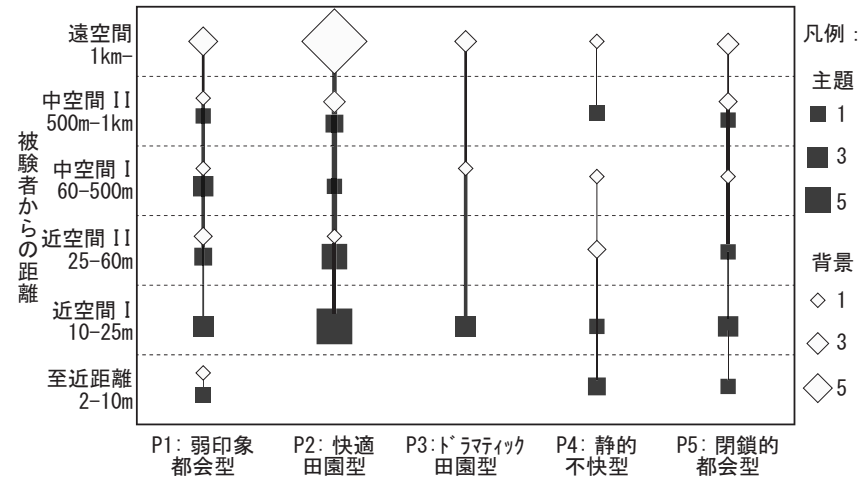

図 9 〈意識型〉別構成要素の距離

このタイプは【UTR】以外は〈人物要素構成型〉であり、主題である 1、2人の人物が〔至近距離〕、たは〔近空間 I〕にいるという特徵 が見られた（図 $5 【 \mathrm{AGO}$ 】）。人物の表情が暗いことに加えて、見る者 にとって迫ってくるように感じられるため＜濁った感じ＞、＜無味 乾燥な感じ>のような不快感を表す心理的評価を受けたと考えられ る。指摘を受けや寸い人物が大きく、見る者に近く描かれているので、 主題に指摘が集中するのではないかと考えがちだが、このタイプの 絵画には全て〈指摘法分析〉で定義した、背景的な要素でありつつ、 主役並に注目を集める図的な地である「仮面の主題」があったこと から、実際は本来の主題以外の要素に着目されることが多いことが 
わかる (図 10)。「閉鎖的都会型」の【KIP】も「静的暗狭型」の〈人 物要素構成型〉と同様に主題が〔至近距離〕にあり、「都会的な感じ」 以外はほとんど共通の評価を受けたが、これも「仮面の主題」のあ る絵画である。描かれた人物の距離感の近さが、かえって見る者の 目を主題から背けさせ、背後や周辺の要素に着目させて主題をわか りにくくしており、それが＜暗い感じ $><$ 狭苦しい感じ $>$ の評価に 影響していると考えられる。

建築要素の描かれ方と心理的評価にも関連性が見られた。「閉鎖的 都会型」は主に都市的な情景を描いており、見る者と主題との距離 は長い傾向がある。にも関わらず＜狭苦しい感じ>が強いのは、背 景の建築物が遠空間より近い〔中空間〕にある絵画が多く、縦型の 構図に複数の建物がひしめいていることで、笨屈な評価を得ている と考えられる。

建築要素の印象が強い「弱印象都会型」は〈注目域分布型〉の中 で左右対称性と水平性の強い〈三角形型〉と〈中央帯型〉が多い傾 向があった。特に「中央帯型」の 4 点の絵画は主題と背景の距離が 近く、主題が〔近空間〕または〔中空間〕にあるという共通の傾向 がある。特に【ESM】と【MEG】は両方とも、〔至近距離〕に人物が描 かれている構図と類似して、〔近空間〕に正対した建築が大きく描か れており、「仮面の主題」を持っている（図11）。しかし、人物が〔至 近距離〕にいる場合より暗狭感が少ない評価を受けた。同様に〔近 空間】に正対した建築がクローズアップされた構図の絵画として「快 適田園型」の【HRU】がある。「弱印象都会型」の【ESM】と【MEG】 と異なる点は、【HRU】には建物の前に庭があり画面中央に大きな木 が配置されていることである。【ES】では建物の前のサインポール に指摘が集まったが、【HRU】ではより大きい樹木に注目が集まるこ とにより注目域が〈十字形型〉になり、〈意識型〉もく田園的な感じ ><澄んだ感じ >が強くなることが示された。

\section{8. まとめ}

西洋絵画の二次元的空間から受ける心理的評価とその構図の特性 との関係を明らかにするために、対象絵画 39 点について、心理的実 験を行った。分析結果の傾向を以下に述べる。

1）もつとも特徵的な心理的評価を受けた絵画は主に自然の情景を描 いており、共通して<開放的な感じ><美しい感じ>などのポジティ ブな評価が高かった。

2）絵画に表現された二次元空間の心理的評価構造を明らかにするた め、因子分析を行って 7 軸の評価軸を抽出した。(1)空間の心地よさ を表す〈快適性因子〉、(2)動きを表現する〈ダイナミック因子〉、(3) 空間の広がりの度合いを表す〈開放性因子〉、(4)空間のドラマ性を表 す〈ドラマティック因子〉、(5)清濁の度合いを表す〈澄清的因子〉、 (6)都会・田園の度合いを表す〈アーバニティ因子〉、(7)空間の雾囲気 を表す〈アンビエンス因子〉。これらの因子からそれぞれ代表心理的 評価尺度を選出した。

3）心理的評価の傾向から、特徴的な評価の型を抽出するため、代表 心理的評価尺度の心理量を類似度としたクラスター分析を行い、5つ のタイプに類型化した。それらをP1：弱印象都会型、P2：快適田園型、 P3：ドラマティック田園型、P4：静的暗狭型、P5：閉鎖的都会型と命 名した。タイプごとに代表心理尺度の心理量と、絵画の構図的特性 を分析した。

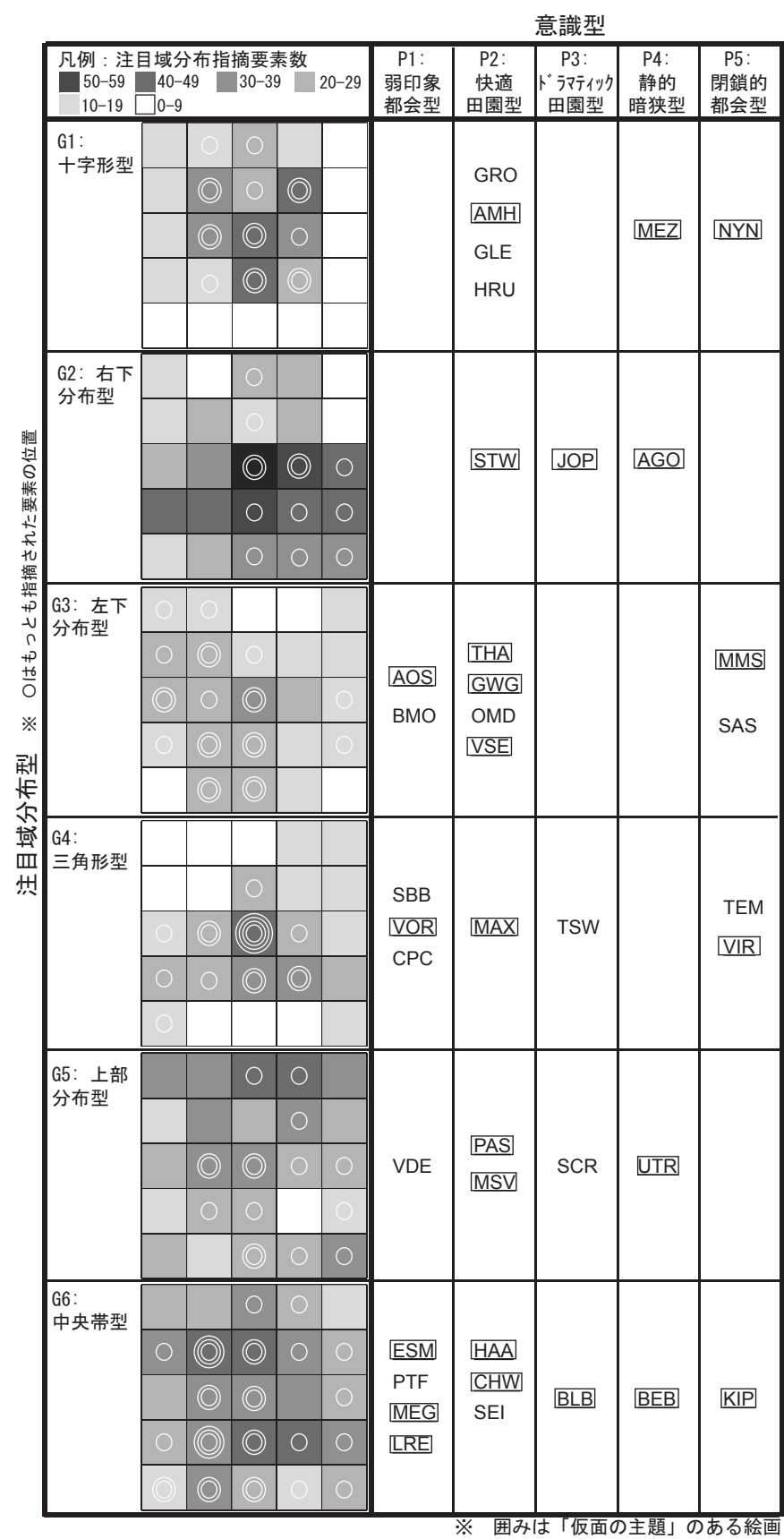

図 $10 〈$ 注目域分布型〉と〈意識型〉の対応関係

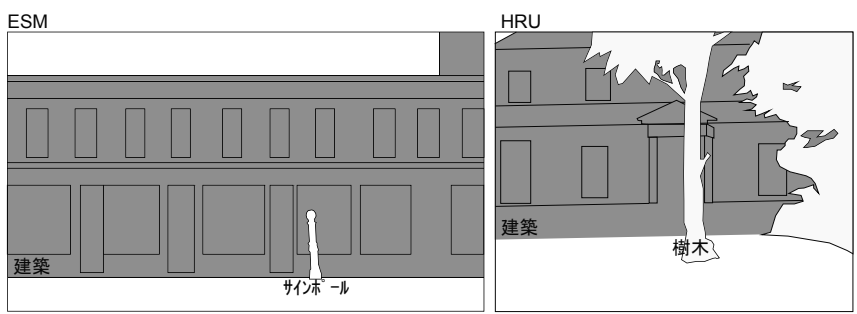

図 11 〈中央帯型〉の【ESM】と〈十字形型〉の【HRU】

4）P1-P2 は主に横型の構図であり、P3-P5 は主に縦型の構図であった。 横型の構図は空間の質や広がりに関する評価、縦型の構図は空間で 起こっている事柄や動作に関する評価が高いことが明らかになった。

5）絵画の空間表現の心理的評価と印象に残る構成要素との相関関係 を把握するため、代表心理的評価尺度の心理量と「人物」「建築」「樹木」 「空」「その他」のカテゴリーに分類した指摘数の相関分析を行った。 
「樹木」の要素がもっとも多くの心理的評価尺度と相関を示し、ポジ ティブな評価に寄与していることが明らかになった。

6）水平に水の要素が配された構図の絵は＜澄んだ感じ $><$ 明るい感 じ>などの評価に関係する。その構図の〔近空間〕に樹木と人物が 配されていると、<澄んだ感じ $><$ 開放的な感じ $>$ の評価がより高 まる傾向が明らかになった。

7）人物は〔近空間〕に複数人集まっていると、背景との距離に関わ らず＜狭苦しい感じ＞と関連する。背景との距離が短い〔至近距離】 や〔近空間]に $1 、 2$ 人の人物が配置された場合は、主題である人物 に注目が集まりにくく、暗く狭い感じの心理的評価を受ける傾向が 見られた。

8）〈十字形型〉と〈左下分布型〉のように、横型構図において、縦 に指摘要素が集中し、余白に背景の広がりがある構図は、広々と開 放的な感じに寄与する。

9）印象に残る要素が水平の幅広い帯状に広がる〈中央帯型〉は「弱 印象都会型」や「快適田園型」のように静的で䨌囲気のある心理評 価を得る傾向が明らかになった。

以上の成果により、西洋絵画の心理的評価は、印象に残る構成要 素とその配置、画面の奥行きの広がりと関係していることが明らか になった。これらの構図特性を考慮することにより、より伝達力の 高い二次元的空間表現につながると考える。

\section{謝辞}

本研究に際し、秋田工業高等専門学校の鎌田光明先生、東京電機 大学の渋谷沙季氏、キョン・ドゥヒョン氏に集計・分析等にあたり ご協力いただいた。実験に当たっては、共立女子大学の高橋大輔先 生に多大なご協力をいただいた。また、東京電機大学の積田洋教授 に多くのご助言をいただきましたことを記して深く感謝いたします。

\section{注}

注 1) 参考文献 2), p. 90

注 2) 参考文献 3), p. 42-43

注 3) 本研究の「建築物」には橋などの構築物を含む。

注 4) SD 法 : 実験の対象となる空間を体験させ、複数の形容詞句対による言語 尺度から評価値を得る心理的評価実験方法。空間研究では空間が人に与 える心理的評価の影響を定量的に得るために使われる。12)

注 5）実空間だけではなく、言語で表現された空間を扱った研究 ${ }^{13)}$ を特に参考 にした。

注 6) 評価の段階が奇数であると形容詞句対の中心の「どちらでもない」とい う評価が増える傾向を加味して、「どちらかと言えば」の評価を得るため、 あえて中心の值のない 6 段階尺度を選定した。

注 7) HP DesignJet T790 ePrinter（最高解像度：2400 X 1200 dpi）を使用し、 出力した。

注 8）SD 法に関して、明確な被験者数について述べられたものはなく、過去の 研究を参考に、また男女の比率は等分に近くなるように努めて被験者数 を決定した。

注 9）絵画は物語性を有しているものも多く、見る者がその意味世界を理解し ているかどうかで、心理的評価も変わってくると思われるが、本研究は 建築図面の空間表現に資寸る認知のフォーマットを明らかにすることを 目指しているため、構成や構図的な観点からのみの評価を行い、被験者 に意味世界を示唆する情報を開示しなかった。

注 10)透視画（特に幾何学的な線遠近法）の手法は、イタリアのルネサンス期 に高さや幅、それに深さを伴った三次元の物体や空間を科学的に二次元 に写し取ることを目的として「発明」された。しかし、前編で述べたよ うに、実際の視知覚とは異なる形式化された空間表現であったが、一旦 それが定着したフォーマットになると、必ずしも厳密に作画されていな くても、透視画は三次元表現として役割を果たすようになった。実際、
本研究の調查対象とした西洋絵画における空間表現においても、線遠近 法が厳密に適応されていない場合もあり、遠近法自体にも空気遠近法の ような、厳密な計測性よりもより心理的、雾囲気醸成的な方法が用いら れることも少なくないが、その中でも【SCR】や【VIR】はあえて線遠近 法を逸脱した空間表現を用いている。

注 11)統計ソフト SPSS

注 12)クラスター分析における類似度間の距離の算出方法は、ユーグリッド距 離による。(統計ソフト SPSS)

注 13)高橋鷹志研究室は対象の持つ大きさと識別距離との関係を調查し、まと めている。見ている人から $2 \sim 10 \mathrm{~m} の$ 範囲は「至近距離」、顔の表情がわ かる $10 \sim 25 \mathrm{~m}$ の範囲は「近空間 $\mathrm{I}$ 、眉や目など顔のパーツが識別でき る $25 \sim 60 \mathrm{~m}$ の範囲は「近空間 I I」、髪と顔が識別できる $60 〜 500 \mathrm{~m}$ 「中空間 I」、建物が立体的に見える $500 \mathrm{~m}$ から $1 \mathrm{~km}$ の範囲を「中空間 II」、 人の存在が識別できる範囲の $1 \mathrm{~km}$ より遠くを「遠空間」と定義している。 本研究ではこの識別尺度を使って絵画の奥行きを推定した。 ${ }^{14)}$

\section{参考文献}

1）松下希和、積田洋：西洋絵画に描かれた建築要素の二次元的な構成の 認知評価の研究、日本建築学会計画系論文集、No.717 p p. 2459-2467, 2015. 11

2）オギュスタン・ベルク：日本の風景・西欧の景観，篠田勝英訳 講談社現 代新書 1990

3） ヴァルター・ベンヤミン：複製技術時代の芸術，佐々木基一ほか訳 晶 文社 1997

4）植田宏、下田雅子、北野隆：絵巻物における建築空間の表現について 1 絵画における空間表現 1 , 日本建築学会大会学術講演梗概集, F-2, pp. 171-172，1995. 08 他

5）仲谷兼人：浮世絵版画の空間表現一浮絵と遠近法を中心として一、大阪 樟法女子大学人間科学研究紀要 (第 5 号)、pp57-69, 2006.01

6) 濱本紳平、積田洋 : 都市空間における<意識型 $>$ 構成の研究、日本建築 学会計画系論文集、No. 623, pp. 101-107，2008. 01

7）積田洋、濱本紳平：＜指摘エレメント構成型＞と＜意識型＞の対応関係 による都市の空間構造の研究、日本建築学会計画系論文集、No。640, pp. 1359-1364，2009. 06

8) Davies, P.J.E, et al., Janson's History of Art, Eighth edition, Prentice Hall, 2011

9) Kleiner, F. S., et al., Gardner's Art Through Ages, Twelfth edition, Wardsworth/Thomson Learning, 2005

10）高階秀爾監修: カラー版西洋美術史 増補新装版、美術出版社、2002. 12

11）永井一正、木島俊介監修：高校美術 I/II 日本文教出版、2014.01

12）日本建築学会編 : 建築・都市計画のための調查・分析方法 改訂版 井 上書院, 2012.05, p. 140

13）積田洋、竹内政裕、鈴木弘樹：俳句から連想寸る心象風景の構成と心理 的評価の研究、日本建築学会計画系論文集、No。669, pp. 2093-2099, 2011. 11

14）高橋研究室編：かたちのデータファイル、彰国社、1984.02 


\title{
STUDY ON RELATIONSHIP BETWEEN PSYCHOLOGICAL EVALUATION AND COMPOSITIONAL CHARACTERISTICS OF SPATIAL REPRESENTATIONS IN WESTERN PAINTINGS
}

\author{
Kiwa MATSUSHITA* \\ ${ }^{*}$ Assoc. Prof., Dept. of Architecture, School of Science and Technology for Future, TDU, M.Arch.
}

The perspective drawings are remarkably useful in expressing the characteristics and atmosphere of the space, while they do not provide the information on the exact scale or dimensions. The atmosphere of the two-dimensional space is created not only by the composition of the stand-alone architecture, but also the overall composition of the background and surrounding elements, such as trees and human figures. The objective of the research is to understand the cognition and psychological evaluation of the perspective images, which represent three-dimensional architecture and spaces in the two-dimensional plane in various frameworks, scale and subject, in order to obtain the insights to our reception of the architectural representation. Following the previous paper, which reported the cognition of the two-dimensional representation of architecture, this paper continues to focus on the Western paintings as a case of the spatial representation in broader frameworks. The psychological evaluation experiment based on the SD methods was conducted to quantitatively measure the ambience perceived by the viewers.

The psychological evaluation experiment was performed using the same 39 paintings as the Indication Methods, between the periods of the Late Renaissance to mid Twentieth century. 50 architecture students ( 22 males, 28 females) were asked to rate their impression at 6 grades between 31 sets of bi-polar adjectives, which are carefully selected through the preliminary experiment. The summary of the research outcome is as follows:

1) The paintings which received the most characteristic evaluations depicted the natural landscape. They were rated highly on the positive evaluation scales, such as <open $>$ and <beautiful $>$.

2) The factor analysis was conducted in order to capture the psychological evaluation structure, and the following 7 factors are obtained. 1. Comfort Factor, 2. Dynamic Factor, 3. Open Factor, 4. Dramatic Factor, 5. Purity Factor, 6. Urbanity Factor, and 7. Ambience Factor. The representative psychological evaluation scales are selected from these 7 factors.

3) To categorize the distinctive types of the reception from the psychological evaluations, <Consciousness-Types>, the Cluster Analysis was performed by taking the average ratings of the 7 representative psychological scales for the paintings as the similarity and they were classified into the following 5 types: P1. Low-Impression Urban Type, P2. Comfortable Rural Type, P3. Dramatic Rural Type, P4. Quiet, Dark and Tight Space Type, P5. Closed Urban Type.

4) P1 and P2 are mostly landscape orientation, while P3-P5 are mostly portrait orientation. The landscape orientation paintings are evaluated highly on the quality and openness of the space, as the portrait orientation paintings are evaluated based on the actions and events in the space.

5) Based on the correlation analysis between the average ratings of the representational psychological evaluation scales and the number of indications obtained by the Indication Experiment, "Tree" elements show the correlations with most number of evaluation scales, which are mostly positive evaluations.

6) The composition which includes water elements in the lower part of the canvas has relationship between the evaluations, such as <pure>, <bright>. If such a composition also has the "tree" and "human" elements in the foreground, the evaluation $<$ pure $>$ and $<$ open $>$ are enhanced.

7) The "human" elements are evaluated <tight space> if the multiple number of them are placed in the foreground regardless of the depth of the background.

8) In the landscape orientation paintings, when the indication focus zone is compact and vertical, the evaluation is broad and open. 